\title{
What Are the Changes in the Use of Space in The Residential Neighborhood of Residence as A Place of Business?
}

\author{
Iin Isnaeni ${ }^{1, a)}$ and Diah Intan Kusumo ${ }^{1, b)}$ \\ ${ }^{1}$ Department of Urban and Regional Planning, Faculty of Engineering, University of Diponegoro, Semarang, \\ INDONESIA \\ a) Corresponding author: iinisnaeni@gmail.com \\ b) diah.dewi@undip.ac.id
}

\begin{abstract}
Kampung Batik Kauman is the first batik village in Pekalongan where located in the center of Pekalongan. Location and development of Kampung Kauman as batik tourism village has an impact on the physical development, one of which is marked by the changes of residential house function into a business house. Based on the phenomenon, the purpose of this paper is to identification space use of business houses in Kampung Batik Kauman. The writer applied quantitative descriptive method. From the research results can be seen that there are five types of business houses in the Kampung Batik Kauman, namely residential houses and batik production; residential houses and batik showrooms; residential houses, production and showroom of batik; residential and boarding houses; and residential houses and trading and services (except batik). Space utilization of home business in Kampung Kauman consists of the type of utilization of mixed and separate business house space.
\end{abstract}

Keywords : use of space, business houses, Kampung Batik Kauman

\section{INTRODUCTION}

House is a type of space which is always associated with human activities [1]. The functions of house, based on [2], consist of three features, namely as a supporter of identity, of family opportunities, and of security. Along with the development process, now the house has transformed its function, in addition to its function as the dwelling place, as a place of business [3]. According to Tipple [4], in spatial terms, the house used as dwellings and businesses utilizes parts of the proportion of space within the house for business.

Based on Sinai [5], in accommodating the change of house function into business, the residents make some adjustments that are divided into four forms, a namely adaptation of family regulations; family adaptation structures; residential mobility; as well as transforming the dwelling to become more feasible. According to Tipple [6], reshaping can be used in several ways including addition, development, reduction of size and total improvement or redevelopment. Changes in residential functions and forms can improve home quality standards, increase owner satisfaction and home dwellers, provide more space to make money through home-based enterprises and rentals, increase investment that triggers economic activity [7].

The transformation of the housing function occurred in areas affected by the development of cities and particular areas, one of them in Kampung Batik Kauman, Pekalongan. According to Wijanarka [8], Kauman is the name of a village that always exists in the spatial cities in Java which is located behind or around the Jami Mosque and is residents by religious administrators of the mosque and their families. According to Zahnd [9], the function of a residential house in Kampung Kauman in each region has different characteristics. In Kampung Kauman, has a characteristic of batik activity. 
Batik activities in Kampung Kauman Pekalongan existed since the early 1900s. Kampung Batik Kauman is the first batik village in Pekalongan; it can be known from the many ancient buildings and the existence of Jami Mosque 'which was founded in 1852 [10]. Kampung Batik Kauman Pekalongan its existence can still be seen, traced and packed as a cultural heritage area because it has unique local potential value, in the form of the heritage of batik process and the relics of the ancient building which shows high cultural value. Based on the historical background and development of Kampung Batik Kauman since 2007, Kampung Batik Kauman was established to be one of batik tourism village in Pekalongan city by Ministry of Tourism and Creative Economy [11].

Based on location, where Kauman located in the center of Pekalongan and the development of Kampung Batik Kauman as a national tourist village indirectly make the living activities, production and trade of batik, go hand in hand in Kampung Batik Kauman. Along with the development of the area and the development of batik activities in Kampung Batik Kauman, there is the transformation of housing function in Kampung Batik Kauman. The Change of function its because the residents change the physical form of their homes to be both at once used as a place of business. Based on the phenomenon, this research aims to identify the space utilization of home business in Kampung Batik Kauman. This research is part of the study of transformation housing function of a residential house in Kampung Batik Kauman Pekalongan. The study discusses the change of house function in Kampung Kauman and factors that influence the community of Kauman Village to change their house function. In this article discusses the space utilization of business house in Kampung Batik Kauman Pekalongan.

\section{METHODOLOGY}

The quantitative method was used in this study. According to Sumanto [12], quantitative method emphasized the objective aspects of measurement of social phenomena described into several components of problems, variables, and indicators. Data collection instruments in this study consisted of questionnaire and observation. Questionnaires were conducted to the people who change the function of a residential house. Sampling technique used in this research was the total sampling because all members of the population were used as a sample. This sampling technique was used when the population was relatively small [13]. The population was meticulously based on the number of residential homes that have changed the function of the dwelling into a business house. The flow in obtaining research information begins by identifying the change function of residential and business houses in Kampung Batik Kauman, Pekalongan. After getting the information then the research continued by doing observations and questionnaires to find out the space utilization of business house in the Kampung Batik Kauman Pekalongan.

\section{RESULT AND DISCUSSION}

\section{Space Utilization Of Business House In Kampung Batik Kauman, Pekalongan}

The development of batik activities and the establishment of Kampung Kauman as a tourist village of batik since 2007 has affected the transformation of house function in Kampung Batik Kauman. This phenomenon occurs because the residents change the function and physical form of their house as a place of dwelling and business. The number of residential houses in Kampung Batik Kauman that change the function is 74 units. There are five types of transformation of function of a residential house in Kampung Batik Kauman, as batik production place, batik showroom, production and showroom of batik, boarding house and trade and service (besides batik). The existence of different types of change of this function makes different types of house space utilization. The following chart type of house space utilization in the business house in the village of batik Kauman, Pekalongan: 


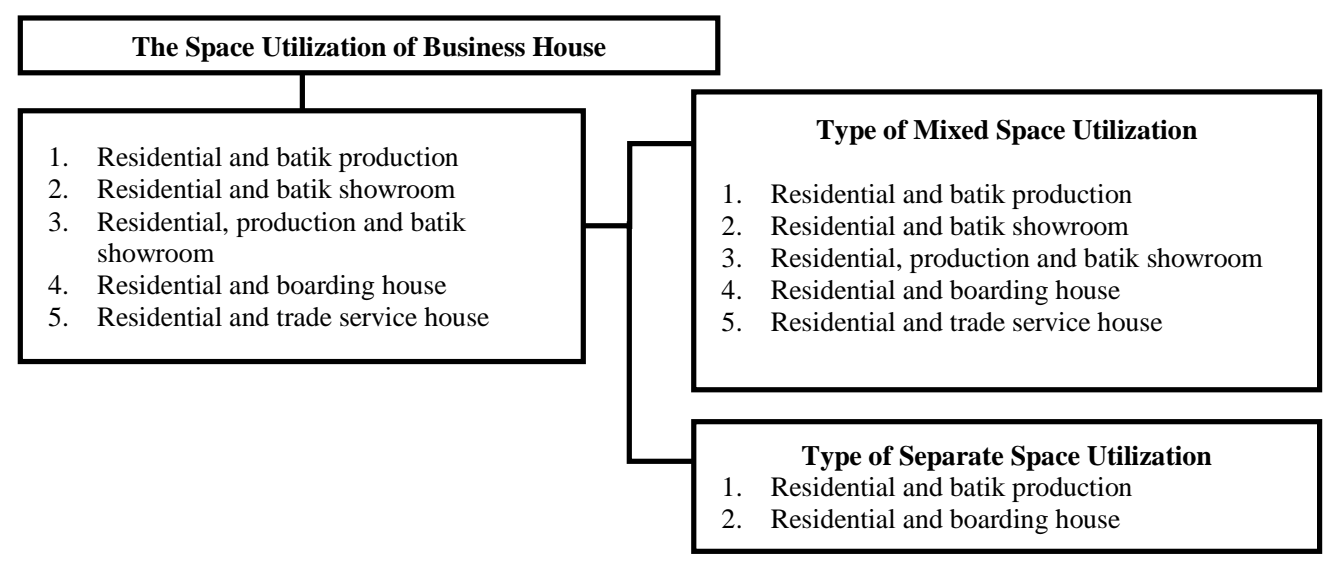

FIGURE 1. Diagram Types of home business space utilization In Kampung Batik Kauman

The type of use of business houses in the Kampung Batik Kauman consisted into two types, the type of mixed house space utilization and the type of separate utilization. The type of mixed of house space utilization is the use of house space in the main building where the primary building function as a dwelling mixes its function as a workplace. However, the primary function as a dwelling is still dominant. On the other hand, the separate utilization type is the use of the house as a dwelling and workplace is in the different building, with location around main house building, but in still in one ownership.

Type of mixed utilization house space consisted of the house which has a function as residential and batik production, batik showroom, production and showroom of batik, boarding house and trade and service but the primary function of the house as a dwelling is still dominant. Meanwhile, the type of separate utilization house space consists the house which has a capacity as residential house and batik production and boarding house. The number of business house type based on function can be seen in table 1 .

TABLE 1. Types of business house utilization based on function

\begin{tabular}{lcc}
\hline \multirow{2}{*}{ Types of house function } & \multicolumn{2}{c}{ Types of business house utilization } \\
\cline { 2 - 3 } & Mixed utilization & Separate Utilization \\
\hline Residential and batik production & 7 & 2 \\
Residential and batik showroom & 11 & - \\
Residential, batik production and showroom & 4 & - \\
Residential and Boarding & 4 & 1 \\
Residential and trade service (except batik) & 45 & - \\
total & 71 & 3 \\
\hline
\end{tabular}

\section{Residential and Batik Production}

The existence of a house has also functioned as a batik production in Kampung Batik Kauman since the 1960s. In Kampung Batik Kauman, nine residential houses have changed their function to residential house and production of batik with a building area of 100 to $400 \mathrm{~m}^{2}$. Out of the nine residential units, there were seven units of the houses whose type was mixed utilization and two units of houses whose type of utilization were separate businesses house space.

1. Residential and Batik Production Type of Mixed space utilization

The change of house function into a residential house and batik production used the back of the house space as a place of production of batik. It is intended that there are differences in the direction of circulation between residential activities and batik activities. Based on space used, the space to production business is permanent. Batik production space is divided into batik room, coloring room, boiling room, drawing room, and drying room were located on the 2nd floor. In storage, raw materials and finished products are stored in a warehouse. 
In Kampung Batik Kauman, a residential house that has changed function into residential houses and batik production has a building area of 100 to $400 \mathrm{~m}^{2}$. The large of rooms that functioned as the production of batik is 20$50 \%$ of the house area. The existence of batik production does not interfere with the dwelling activities, and this happens because there is a boundary between the function for residential with production activities.

\section{Residential and Batik Production Type of Separate Space Utilization}

In Kampung Batik Kauman there are two a residential house and production of batik which are separate house utilization type. In the changing function of residential houses into residential and batik production, batik production is located at a distance of 100 meters from the main house. Because of different buildings, there are differences in the direction of circulation between dwelling activities and batik activities, so there is a boundary between the function of the house space for residential activities with production activities. From the space used, the batik production business is permanent, and its space use remains as the production of batik.

The size of residential houses that have changed function into residential houses and batik production separate utilization type has an area of 100 and $400 \mathrm{~m} 2$ and all parts of the house used as a batik production, with the location of residential and production have a different building. Batik production room is divided into batik room, coloring room, and boiling room, and drying room and storage room. The drying room is located on the second floor because of the limited area. In storage, raw materials and finished products are stored in warehouses. There is one stage of the process that is not done in the production house that is the process of colet. Usually, the process is done by workers in their house.

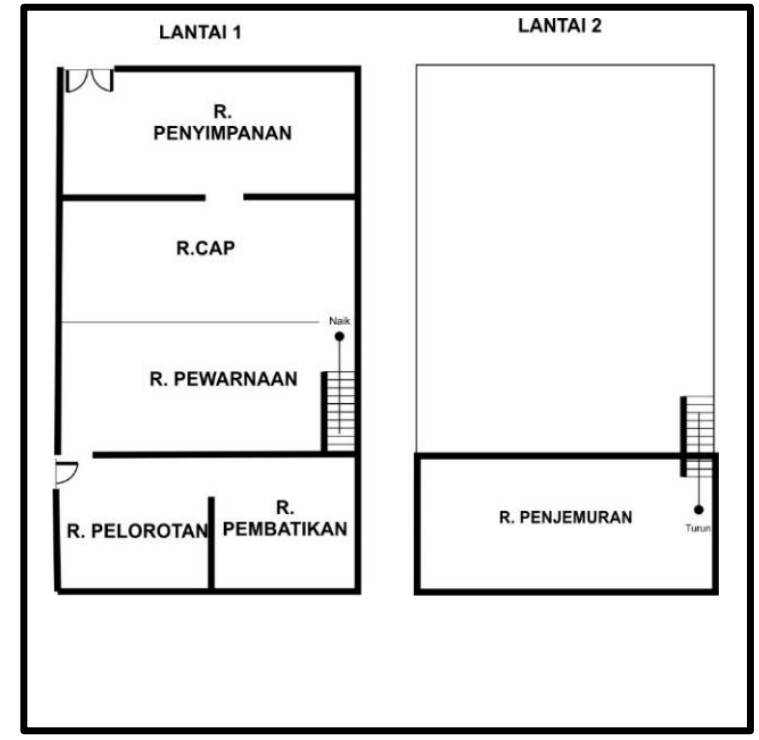

a) Residential and Batik Production Type of Mixed space utilization House of Rizam Kamal, Kauman V/7

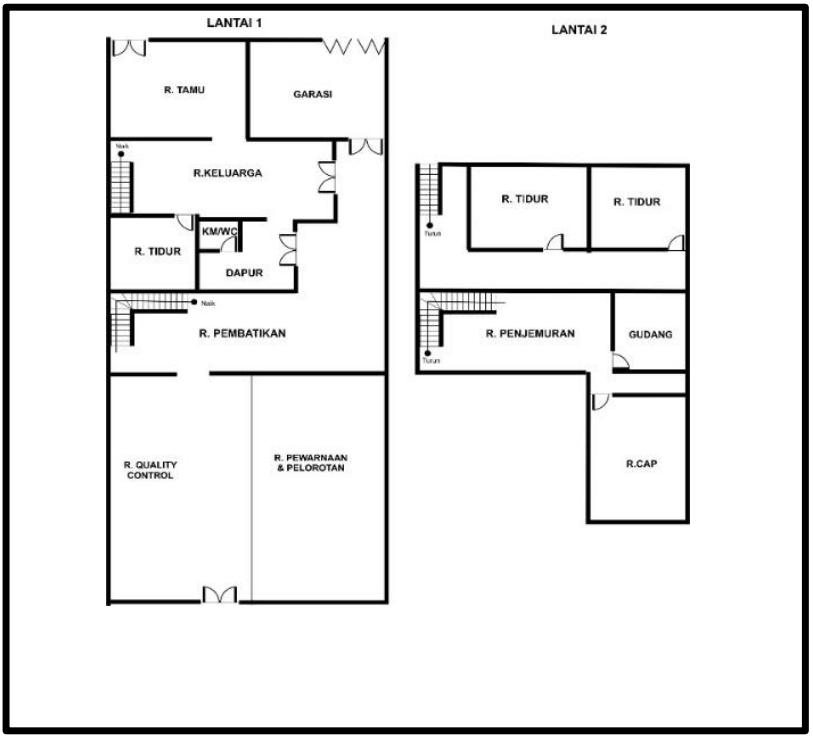

b) Residential and Batik Production Type of Separate Space Utilization Batik House of HM. Chairi, Kauman gang I

FIGURE 2. Sketch of Residential and Batik Production house

\section{Residential and Batik Showroom}

Batik Showroom is one type of batik business activity in Kampung Batik Kauman in the form of sales activities or marketing of batik products from various places. The change of function of the residential house become residential and batik showroom in Kampung Batik Kauman there are two types, that is change function by utilizing partially living room as showroom and change function by changing the entire living room into a showroom. 
On the change of function by utilizing part of the living room as a showroom, the living room that usually serves as a space for receiving guests is also used as a batik showroom. In this type, the boundary between the function of the house as the residence and batik showroom is not apparently visible because of the same circular direction between the residential activities and showroom activities. From the space usage, the space used as the showroom is permanent, its use remains as a batik showroom.

Meanwhile, on the change of function by changing the function of the living room into a showroom, all parts of the living room converted into a batik showroom so that the house does not have a living room. In this type, the boundary between the function of the house as dwelling and showroom of batik is visible but has the same circulation direction between residential activities and showroom activities. From the space usage, the space used to the showroom is permanent, its use remains as a batik showroom.

The residential house that has changed the function into residential and batik showroom in Kampung Batik Kauman have a building area of 75 to $300 \mathrm{~m}^{2}$. The space utilization that functioned as a showroom that is 10 to $20 \%$ of the area of the house, for example in a residential house with an area of $300 \mathrm{~m}^{2}$ and $48 \mathrm{~m}^{2}$ living room area using a space of $24 \mathrm{~m}^{2}$ for the showroom business space and residential house with an area of $75 \mathrm{~m}^{2}$ utilizing an area of $12 \mathrm{~m}^{2}$ for showroom business room. In the storage, items to be sold in the showroom is kept one room with a showroom this is done for reasons of the effectiveness of space use. The existence of batik showroom does not interfere with the activities of the residents of the house, and this happens because the showroom makes more comfortable for the owner in overseeing the activities in the showroom. Here is an example of the use of residential dwelling space and batik showroom at Kampung Batik Kauman.

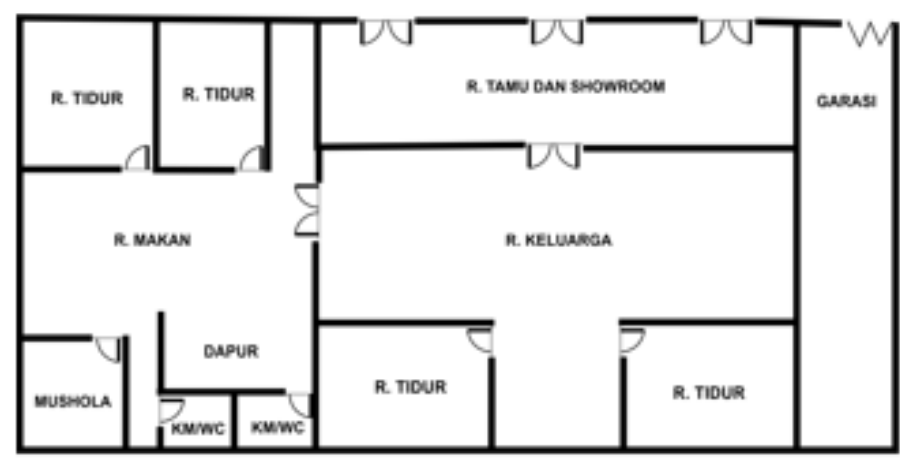

a) Function shifting of residential house and showroom that utilize most of the living room ( House of Mr. Mahdi Maksum)

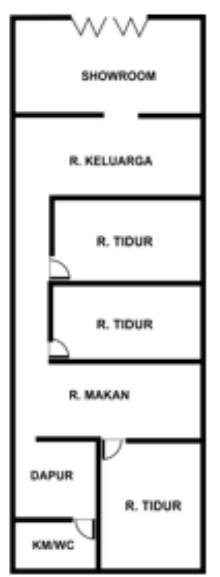

b) Function shifting of residential house and showroom that utilize the entire living room (House of Mr. Helmi)

FIGURE 3. Sketch of Residential and Batik Showroom

\section{Residential, Production and Showroom of Batik}

Transformation of house function into a residential, production and batik showroom is one of the changing function of the house where the house as a residential mixed its function as a place of production and showroom of batik. However, the main function of the house as a residential is still dominant. In Kampung Batik Kauman, there are four residential houses that have changed the function into residential, production and showroom. Residential house that has changed the function into a residential, production and showroom batik in Kampung Batik Kauman is a house with a building area of 200 to more than $800 \mathrm{~m}^{2}$.

In the changing function into residential, production and showroom of batik, the room used as a batik production is the back of the house and the room used as a showroom is the front of the house. Batik production space is divided into batik room, coloring room, boiling room, and drying room that located on the second floor. From the space use, the space used to production and showroom business is permanent, its use remains as production and 
showroom batik. The transformation of house function of residential to a place of production and a showroom had a difference of direction of circulation between residential activity and production activity or showroom.

The primary coefficient of the house building that has changed the function into production and showroom of batik is more than $100 \%$, and floor coefficient of the building is two floors. For example, the production and showroom house owned by Mr. Rikza Setiabella has a land area of $300 \mathrm{~m}^{2}$ and building area $>400 \mathrm{~m}^{2}$ with building floor coefficient 2. Room area functioned as production and showroom are $\pm 50 \%$ of house area or area of $\pm 200 \mathrm{~m}^{2}$. The presence of batik production and showroom does not interfere with the activities of the residents of the house, in addition to the location of production located at home also facilitate the owner in supervising the production process.Here is an example of space utilization of house as residential, production and showroom batik in Kampung Batik Kauman.

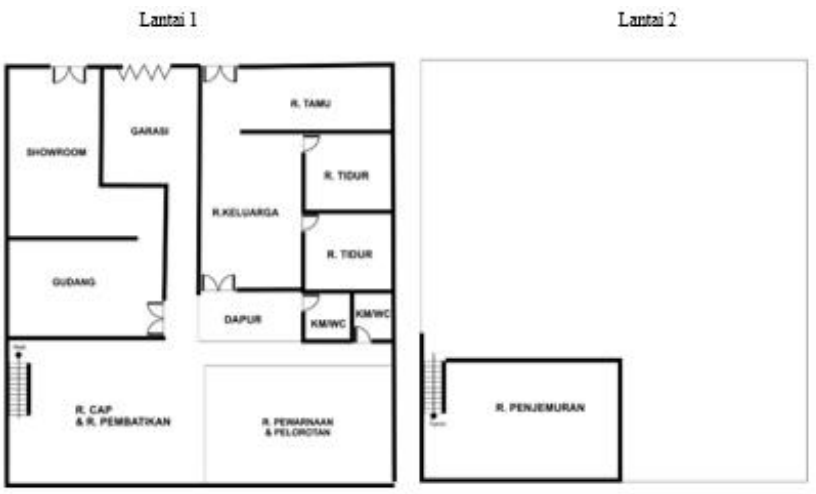

House of Mr. Rikza Setiabella, Kauman gang V/11

FIGURE 4. Sketch of Residential Production and Showroom of Batik

\section{Residential and Boarding House}

In this study, that is classified into the change of house function as residential and boarding houses are residential that function part of the space for a temporary dwelling leased. The development of residential and boarding houses in the kampung batik Kauman began to occur since the 1990s until now. In Kampung Batik Kauman there is five residential house that has shifted function to the residential and boarding house. From 5 residential units, there are four housing units which are the type of utilization of mixed house business space and 1 unit of the house which is the type of utilization of separate business house space.

\section{Residential and Boarding House Type of Mixed space utilization}

In this study that classified as a residential and boarding house of mixed utilization, the type is a residential house that functioning part of the space of his house for a temporary dwelling rented or boarding house. In Kampung Batik Kauman, four residential houses that have changed function into a residential house and boarding house with mixed house type or reside in one building between residential house and boarding house.

Residential and boarding house in Kampung Batik Kauman has a building area of 100 to $600 \mathrm{~m}^{2}$. Boarding house in Kampung Batik Kauman has 5 to 15 rooms. From the use of space, the space used is permanent, its use remains as a boarding house. The primary coefficient of mixed boarding house building is $100 \%$, wherein Mrs. Mariyah's boarding house has a land area of $600 \mathrm{~m}^{2}$ and a total building area of $600 \mathrm{~m}^{2}$. The space that is functioned as a board about $50 \%$ of the house area or about $300 \mathrm{~m}^{2}$ with the coefficient of the floor of the building is one floor. In the use of space, there is a different circulation between the function of residential space and boardroom functions, so there is a clear boundary between the function of the home space for residential activities with the activities of boarding. The existence of the board does not interfere with the activities of the inhabitants of the house; this happens because the difference between the circulation and the clear boundaries between the territory of residential space and boarding room also makes the existence of boarding house does not interfere with residential activities. Here is an example of the residential and boarding house of mixed type in Kampung Batik Kauman. 
2. Residential and Boarding House Type of Separate space utilization

In the type of separate house space in a house that has changed the function to a residential and boarding house, the utilization of house space as a different dwelling with the house plot used as a boarding house, with the distance of residential and boarding house as far as 50 meters. In Kampung Batik Kauman there is one residential house which has changed function into a residential house as well as a boarding house with the type of separate type with residential house building.

The area of the house used to be a residential and boarding house a separate type is $300 \mathrm{~m} 2$. The basic coefficient of building the sample house taken is $100 \%$, where the existing land area is $300 \mathrm{~m} 2$, and the total building area is $300 \mathrm{~m} 2$. The space that is functioned as a boarding house is the entire area of the existing house with the coefficient of the floor of the building is one floor. In the use of space, there is a circulation that connects a house that is used as a boarding house with a house occupied by the owner of the board as a dwelling. From the use of space, the space used to make business boarding house is permanent, its use remains as the boarding house. re is an example of the residential and boarding house in Kampung Batik Kauman :
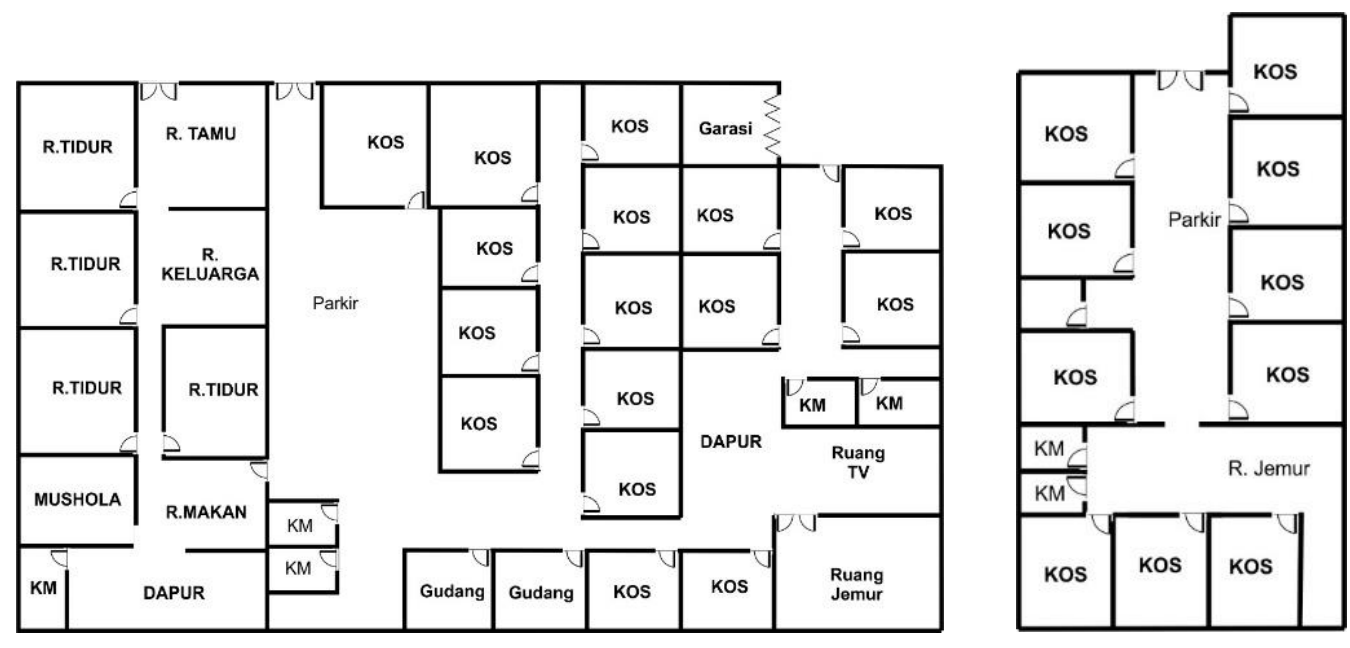

a.) Residential and Boarding House Type of Mixed space utilization

House of Mrs. Hj. Mariyah, Kauman gang IV/17 b.) Residential and Boarding House Type of Separate space utilization Boarding House of Mrs. Robiah, Kauman gang IV

FIGURE 5. Sketch of Residential and Boarding House

\section{Residential and Trade Service House (Except Batik)}

In this study that classified as house function transformation as residential house and trade and services (except batik) is a residential house that functioned part of the space of his house for trading activities or services other than batik products. In Kampung Batik Kauman, there are 45 residential houses which have changed function into residential houses and trade and services. Most of the products are daily household necessities or groceries, snacks, restaurants, laundry, salon, and other. In Kampung Batik Kauman, residential houses and trading services that sell basic foods and snacks have a building area of 36 to more than $300 \mathrm{~m}^{2}$. The residential house and trade services which open a restaurant business have a building area of 100 to $250 \mathrm{~m}^{2}$. The residential houses and trading services which open laundry and salon businesses have a building area of 54 to $250 \mathrm{~m}^{2}$; and the residential house and trade services that sell other goods such as clothing and others have a building area of 60 to $350 \mathrm{~m}^{2}$. Here is an example of the use of residential space and service trade (except batik) in Kampung Batik Kauman. 


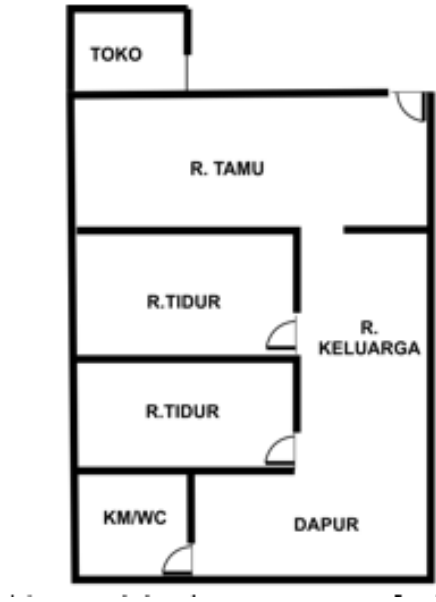

a) Residential house that utilize front and side yard for business House of Mrs. Mayuni, Kauman gang XV/5)

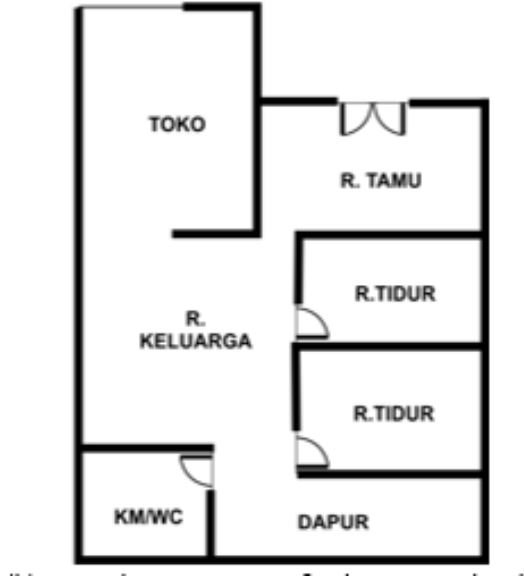

b) Residential house that utilize living space for business House of Mrs. Nurul (Kauman gang I/14)

FIGURE 6. Sketch of Residential and Trade Service House

Based on the observation, the use of residential houses as well as trade and services in Kampung Batik Kauman is divided into two types, 1) residential homes that use the front room or next to his house as a business space and the second house that utilizes some residential space, for example the living room, which originally functions as a place to receive guests changed has a double function that is a living room and business space.

In the change function of residential function into residential and trade and services (except batik) has characteristics space used to business is permanent, its use remains as a trading and service business. The basic coefficient of the house building which has changed the function of residential as well as trade and services (except batik) is $70-100 \%$ with the building floor coefficient is one floor. In the sample house owned by Sumarni has a building coefficient of $100 \%$ with a land area of $80 \mathrm{~m}^{2}$ and building area of $80 \mathrm{~m}^{2}$ with the coefficient of the floor of the building is one floor. While the second sample, house owned by Nurul has a building base coefficient of $90 \%$ with a land area of $100 \mathrm{~m}^{2}$ and a building area of $90 \mathrm{~m}^{2}$ with floor coefficient of the building is one floor with the space used as a business space of 10-30\% of the house. The existence of a trade or service business does not interfere with the activities of residents, and this happens because the residents of the house already feel familiar with the changes that occur.

\section{Synthesis of the Type of Business House Space Utilization in Kampung Batik Kauman}

In Kampung Batik Kauman there are five types of changing a house function of residential houses: place of batik production, batik showroom, production and showroom batik, boarding house and trade and services. The space utilization type of business house in Kampung Batik Kauman divided into two types, the type of space utilization of mixed house and separate. Explanation table of the characteristics of the mixed space utilization of business house can be seen in table 2, and explanation table of the characteristics of the separate space utilization of business house can be seen in table 3 . 
TABLE 2 Characteristics the business house of mixed space utilization type

\begin{tabular}{|c|c|c|c|c|c|}
\hline \multirow[b]{2}{*}{$\begin{array}{c}\text { Mixed } \\
\text { space } \\
\text { utilization } \\
\text { type }\end{array}$} & \multicolumn{5}{|c|}{ Characteristics } \\
\hline & $\begin{array}{l}\text { Utilization of space } \\
\text { resources }\end{array}$ & $\begin{array}{c}\text { House } \\
\text { Area }\end{array}$ & $\begin{array}{l}\text { Percentage } \\
\text { of house } \\
\text { space } \\
\text { utilization } \\
\end{array}$ & House Territory & $\begin{array}{l}\text { The existence of the } \\
\text { utilization of other } \\
\text { functions }\end{array}$ \\
\hline $\begin{array}{l}\text { Residential } \\
\text { and batik } \\
\text { production }\end{array}$ & $\begin{array}{l}\text { Utilize the house } \\
\text { space in the main } \\
\text { building for business } \\
\text { activities }\end{array}$ & $\begin{array}{c}100- \\
400 \mathrm{~m}^{2}\end{array}$ & $\begin{array}{l}20-50 \% \text { of } \\
\text { the house } \\
\text { area }\end{array}$ & $\begin{array}{l}\text { there is a boundary } \\
\text { between the function } \\
\text { of house space for } \\
\text { residential with } \\
\text { workplace }\end{array}$ & $\begin{array}{l}\text { Business activities do } \\
\text { not interfere dwelling } \\
\text { function }\end{array}$ \\
\hline $\begin{array}{l}\text { Residential } \\
\text { and batik } \\
\text { showroom }\end{array}$ & $\begin{array}{l}\text { Utilize the house } \\
\text { space in the main } \\
\text { building for business } \\
\text { activities }\end{array}$ & $\begin{array}{c}75- \\
300 \mathrm{~m}^{2}\end{array}$ & $\begin{array}{l}10 \%-20 \% \\
\text { of the house } \\
\text { area }\end{array}$ & $\begin{array}{l}\text { there is not a } \\
\text { boundary between } \\
\text { the function of house } \\
\text { space for residential } \\
\text { with workplace }\end{array}$ & $\begin{array}{l}\text { Business activities do } \\
\text { not interfere dwelling } \\
\text { function }\end{array}$ \\
\hline $\begin{array}{l}\text { Residential, } \\
\text { batik } \\
\text { production } \\
\text { and } \\
\text { showroom }\end{array}$ & $\begin{array}{l}\text { Utilize the house } \\
\text { space in the main } \\
\text { building for business } \\
\text { activities }\end{array}$ & $\begin{array}{l}200-> \\
800 \mathrm{~m}^{2}\end{array}$ & $\begin{array}{l} \pm 50 \% \text { of } \\
\text { the house } \\
\text { area }\end{array}$ & $\begin{array}{l}\text { there is not a } \\
\text { boundary between } \\
\text { the function of house } \\
\text { space for residential } \\
\text { with workplace }\end{array}$ & $\begin{array}{l}\text { Business activities do } \\
\text { not interfere dwelling } \\
\text { function }\end{array}$ \\
\hline $\begin{array}{l}\text { Residential } \\
\text { and } \\
\text { Boarding }\end{array}$ & $\begin{array}{l}\text { Utilize the house } \\
\text { space in the main } \\
\text { building for business } \\
\text { activities }\end{array}$ & $\begin{array}{c}100- \\
600 \mathrm{~m}^{2}\end{array}$ & $\begin{array}{l}30-50 \% \\
\text { of the house } \\
\text { area }\end{array}$ & $\begin{array}{l}\text { there is a boundary } \\
\text { between the function } \\
\text { of house space for } \\
\text { residential with } \\
\text { workplace }\end{array}$ & $\begin{array}{l}\text { Business activities do } \\
\text { not interfere dwelling } \\
\text { function }\end{array}$ \\
\hline $\begin{array}{l}\text { Residential } \\
\text { and trade } \\
\text { service } \\
\text { (except } \\
\text { batik) }\end{array}$ & $\begin{array}{l}\text { Utilize the house } \\
\text { space in the main } \\
\text { building for business } \\
\text { activities }\end{array}$ & $\begin{array}{c}36- \\
300 \mathrm{~m}^{2}\end{array}$ & $\begin{array}{l}10-30 \% \text { of } \\
\text { the house } \\
\text { area }\end{array}$ & $\begin{array}{l}\text { there is a boundary } \\
\text { between the function } \\
\text { of house space for } \\
\text { residential with } \\
\text { workplace }\end{array}$ & $\begin{array}{l}\text { Business activities do } \\
\text { not interfere dwelling } \\
\text { function }\end{array}$ \\
\hline
\end{tabular}

TABLE 3. Characteristics the business house of separate space utilization type

\begin{tabular}{|c|c|c|c|c|c|}
\hline \multirow[b]{2}{*}{$\begin{array}{l}\text { Separate } \\
\text { space } \\
\text { utilization } \\
\text { type }\end{array}$} & \multicolumn{5}{|c|}{ Characteristics } \\
\hline & $\begin{array}{l}\text { Utilization of space } \\
\text { resources }\end{array}$ & $\begin{array}{c}\text { House } \\
\text { Area }\end{array}$ & $\begin{array}{c}\text { Percentage of } \\
\text { house space } \\
\text { utilization }\end{array}$ & House Territory & $\begin{array}{c}\text { The existence } \\
\text { of the } \\
\text { utilization of } \\
\text { other functions }\end{array}$ \\
\hline $\begin{array}{l}\text { Residential } \\
\text { and batik } \\
\text { production }\end{array}$ & $\begin{array}{l}\text { Utilize the space of } \\
\text { houses around the } \\
\text { main house building } \\
\text { for workplace }\end{array}$ & $\begin{array}{l}100- \\
400 \mathrm{~m}^{2}\end{array}$ & $\begin{array}{l}\text { Not use the main } \\
\text { house building }\end{array}$ & $\begin{array}{l}\text { there is a } \\
\text { boundary between } \\
\text { the function of } \\
\text { house space for } \\
\text { residential with } \\
\text { workplace }\end{array}$ & $\begin{array}{l}\text { Business } \\
\text { activities do not } \\
\text { interfere } \\
\text { dwelling } \\
\text { function }\end{array}$ \\
\hline $\begin{array}{l}\text { Residential } \\
\text { and } \\
\text { Boarding }\end{array}$ & $\begin{array}{l}\text { Utilize the space of } \\
\text { houses around the } \\
\text { main house building } \\
\text { for workplace }\end{array}$ & $\begin{array}{l}100- \\
200 \mathrm{~m}^{2}\end{array}$ & $\begin{array}{l}\text { Not use the main } \\
\text { house building }\end{array}$ & $\begin{array}{l}\text { there is a } \\
\text { boundary between } \\
\text { the function of } \\
\text { house space for } \\
\text { residential with } \\
\text { workplace }\end{array}$ & $\begin{array}{l}\text { Business } \\
\text { activities do not } \\
\text { interfere } \\
\text { dwelling } \\
\text { function }\end{array}$ \\
\hline
\end{tabular}


Based on the table, it can be seen that type of mixed utilization space of business house has different characteristics. But of the overall, there is one similar characteristic that is the business activities not interfere with residential activities. Meanwhile, from the percentage of the utilization of house space, the changed house becomes a dwelling, production and showroom have the most significant percentage of the utilization of the area of house space, and house as dwelling and trade and services (except batik) have the lowest percentage of utilization of house space.

In addition, on the change function of the house with a separate type has the same characteristics of the utilization of some space around the house of the main house to perform business activities of batik production and boarding. The location of batik production is at a distance of 10-50 meters from the main house which functioned as a dwelling. Since the production and boarding functions are in different buildings from the main house, there is a boundary between the function of the house space for residential activities with the activities of the board and its existence does not interfere with the function of the dwelling.

\section{CONCLUSION}

Based on the development of surrounding area and the development of batik activities in Kampung Batik Kauman, there is a change of house function. The change happened because the residents change the physical form of their house being a place of business. The number of residential houses that change the function is 74 . The business house in Kauman batik Kauman consist of 9 residential house and batik production, 11 residential house and showroom, four residential house, production and showroom of batik; 5 residential and boarding house and 45 residential and trade and services (except batik).

Types of business houses in Kauman batik village are divided into two types, the type of utilization of mixed and separate house space. Mixed and separate space utilization have different characteristics. But of the overall, there is one similar characteristic, and business activities do not interfere with residential activities. Meanwhile, when viewed from the percentage of the utilization of house space, the house change function becomes residential, production and showroom batik has the largest percentage of the utilization of house space, and the house change function into residential and trade and services (except batik) has the lowest percentage of utilization of house space. Related to the transformation housing function in Kampung Batik Kauman, need to do further research related whether the change of house function in Kampung Batik Kauman causing disturbance to the environment.

\section{REFERENCES}

[1] L. Wardani, "Pola Tata Letak Ruang Hunian-Usaha Pada Rumah Tinggal Type Kolonial di Pusat Kota Tuban,” Dimens. Inter., vol. 21, pp. 37-50, 2005.

[2] J. Turner, Housing by People: Towards Autonomy in Building Environments. New York: Pantheon Books, 1976.

[3] A. Hapsari and A. Syahbana, "Pergeseran Fungsi Rumah Hunian di Kampung Kauman Semarang," J. Tek. PWK UNDIP, vol. 2, no. 1, pp. 168-182, 2013.

[4] G. Tipple, "Settlement upgrading and home-based enterprises: Discussions from empirical data," Cities, vol. 21, no. 5, pp. 371-379, 2004.

[5] I. Sinai, "Moving or improving: Housing adjustment choice in Kumasi, Ghana," Hous. Stud., vol. 16, no. 1, pp. 97-114, 2001.

[6] A. G. Tipple, "Self-Help Transformations to Low-Cost Housing," vol. 14, no. 2, 1992.

[7] A. G. Tipple and A. Salim, "User-initiated extensions as housing supply: A study of government-built lowcost housing estates in Malaysia," vol. 21, 1999.

[8] Wijanarka, Semarang Tempo Dulu: Teori Desain Kawasan Bersejarah. Semarang. Semarang: Ombak, 2007.

[9] M. Zahnd, Model baru perancangan kota yang kontekstual. Strategi Arsitektur. Yogyakarta: Kanisius, 2008.

[10] M. Damayanti and Latifah, "Strategi Kota Pekalongan Dalam Pengembangan Wisata Kreatif Berbasis Industri Batik," J. Pengemb. Kota, vol. 3, no. 2, pp. 100-111, 2015.

[11] W. Sunarjo, Mutadin, and Maghfiroh, "Identifikasi Lima Tahun Pasca Pengukuhan Batik Oleh Unesco Terhadap Perkembangan Ikm Batik Di Kota Pekalongan,” J. Litbang Kota Pekalongan, p. 71, 2014. 
[12] Sumanto, Metodologi Penelitian Sosial Pendidikan: APlikasi Metode Kuantitatif dan Statistika dalam Penelitian. Yogyakarta: Andi, 1995.

[13] Sugiyono, Metode Penelitian Pendidikan Pendekatan Kuantitatif Kualitatif dan R\&D. Bandung: Alfabeta, 2010. 